\title{
Dinner with Mock Faustus: Multilingual Cuisine Cooks the Identity ${ }^{1}$
}

\author{
MĀRTIN̦Š LAIZĀNS
}

\begin{abstract}
Phenomena related to gastronomy form an important part of both individual and collective identities. The gastronomical dimensions of literature can often be perceived as a commentary on the political, historical and societal, going beyond just the food. As cuisines are becoming more mixed globally, languages describing gastronomical scenes in literature are also becoming more multilingual.

The novel Mock Faustus (1973), by the Latvian writer Marǵers Zariņš, fuses the gastronomical and the multilingual to the extreme, producing a utopian linguistic hybrid of the Latvian language to which a mix of foreign languages and countless intertextual references are added. This is achieved by the gastronomical vocabulary and imagery omnipresent in the narrative of writing a fictional cookbook. The depiction of gastronomical phenomena allows Zarinšs to indirectly comment on Latvian history from the 1930s to 1945 and the confused and fragmented identities of these times.
\end{abstract}

Keywords: Faustus; multilingualism; intertextuality; gastropoetics; gastronovel; gastroliterary; identity

Studying food in literature is an enjoyable experience. However, it is also a challenging one. In cooking, every ingredient and every step of a recipe are important. The same applies to food in literature - regardless of whether a gastronomical passage in a text is intentional or accidental, it can be of great significance for the reader, allowing them to interpret both the direct message of a text and the one contained between the bites.

Gastropoetics (Parama 2002) shows how food-related phenomena function in literary texts and what the depicted phenomena reveal about individuals and society. A seminal starting point for gastropoetical research is an essay by Roland Barthes, Pour une psycho-sociologie de l'alimentation contemporaine

1 This article was developed in the framework of project No. lzp-2019/1-0294 National Identity: Gastropoetic Aspect. Historical, International and Interdisciplinary Contexts, funded by the Latvian Council of Science. This version of the article is a shorter version of the article listed in References as Laizāns 2020b. 
(1961), in which the gastronomical realm of culture is characterised as a sign system that produces its own cultural meanings. A counterpart to this essay is the Mythologiques (1964-1971), by Claude Lévi-Strauss, where the role of food as an essential component of any culture is established.

The term culinary text denotes any type of text that deals with gastronomy (for example a cookbook), whereas gastronovel (Radu 2011) refers to novels in which the gastronomical is of major significance. The term recipistolary prose (Witt 1999: 11) is applied to texts in which the narrative is interspersed with recipes, for example Šampinjonu deriba (The Champignon Testament, 2002), by the Latvian writer Laima Muktupāvela. For the sake of the argument of this article, all literary texts that have a considerable amount of the gastronomical can be called gastroliterary texts.

The role of food varies in different literary texts - it can be central to the work (for example Gargantua et Pantagruel (1532-1564), by the French writer François Rabelais) or be only of marginal importance but still reveal important meanings for the whole text. Roland LeBlanc, in his article on Nikolai Gogol's Dead Souls (1842), writes that "indeed, it would be impossible to extract gastronomy from Dead Souls without destroying its meaning" (LeBlanc 1988: 77). Speaking about the ever-more-present mixing of cuisines and languages, the semiotician Fabio Parasecoli adds that "as the level of complexity grows, in order to be decoded, food codes must be interpreted in connection with wider cultural 'texts'" (Parasecoli 2011: 655). For texts in which the gastronomical prevails, an interdisciplinary (and at times eclectic) approach must be adopted; this is indicated by the German literary scholar Gerhard Neumann both in a general article, Jede Nahrung ist ein Symbol (Neumann 1993b), and with a gastronomical analysis of Babette's Feast by Karen Blixen (Neumann 1993a).

The food writer Kyla Wazana Tompkins concludes about gastroliterary texts that

the meal is a cultural text in and of itself, which can be read formally - through the differential relationships between their separate parts - and in terms of the larger narratives of national/cultural identity that surround it. (Tompkins 2005: 252)

The close connection between food and (national) identity is also indicated by Annette Cozzi in the foreword to her monograph on food in nineteenth-century British literature: "food is one of the most fundamental signifiers of national identity, and literary representations of food [...] reveal how that identity is culturally constructed" (Cozzi 2010: 5). The movie critic Anne Bower also notes the plenitude of the gastronomical as a sign, mentioning "food's ability to serve as a remarkably concentrated signifier - a powerful semiotic system that effectively 
communicates ideas about cultural formation and identity" (Bower 2004: 10). She adds that "when food appears in a film it is loaded with much more than calories" (Bower 2004: 12), an idea borrowed from the article "Edible Ecriture" by Terry Eagleton, where, speaking about food representation in literature, he states: "If there is one sure thing about food, it is that it is never just food [...] Like the post-structuralist text, food is endlessly interpretable" (Eagleton 1997). The literary critic Gitanjali Shahani also points to the gastronomical as being both extratextual and extra-gastronomical at the same time, in the virtue of condensing all of the realms of interpretation together: "To study the gastronomic interjection is then to study the literary, material, and cultural contexts in which it was uttered" (Shahani 2018: 4).

As the societies we live in are becoming increasingly multilingual, communities are also becoming more multiculinary than ever. Globalisation has made various cuisines available in most parts of the world. Thus, it is not only cuisines that mix and create hybrids, the introduction of foreign cuisines brings with it linguistic changes, and menus are, as a rule, multilingual. One recent example of where the mix of both cuisines and languages is apparent is the 'Latvian' food knapas - small entrées made from traditional Latvian products. The name is a mix of the Spanish word tapas and a widely used Latvian loanword from German, knapp, thus producing a novel Latvian bite-sized snack and a linguistic hybrid at the same time.

To illustrate the language use in the novel Mock Faustus, the Latvian translator of James Joyce's Ulysses Dzintars Sodums should be quoted: "Man garšo valoda kā kūka" ('I enjoy language just as a cake'; LSM.lv 2017). The gastronovel Mock Faustus brings with it a mix of many languages, and the reading of it can be regarded as having a cake from a linguistic standpoint. Zariņš uses mealtimes and everything related to them as the ultimate cultural experience. For this reason, the prevalence of gastronomical imagery and language related to it poses certain challenges for the comprehension of the text. To paraphrase a commonplace idea in (literary) food studies expressed by Mary Douglas (Douglas 1972), it should be argued that in Zarinšs' case, it is a task of 'deciphering a literary meal'.

The Latvian composer and writer Margers Zariņš was born in 1910 (and died in 1993). In 1969, at the age of 59, he made his debut as a writer with the publication of Elizejas lauku Mocarts (Mozart of Elysian Fields). His first story collection, Saulrietu violetās èrgeles (The Purple Organ of Sunsets), was published in the subsequent year, and his first novel, Viltotais Fausts, jeb, Pārlabota 
un papildināta pavārgrämata (Mock Faustus, or, The corrected complemented cookbook), ${ }^{2}$ appeared in print in 1973.

The first reactions to the novel indicated the utter incomprehensibility of the language used in the novel. Three years later, in 1976, a complement to the novel was published that contained about 1,350 entries that explained unfamiliar words and expressions used in the novel.

The literary style of Zarinš was in strong opposition to the prevailing poetics of Latvian literature of the sixties and seventies. He remained true to his metafictional style, hybrid genres and interplay of languages throughout his literary career. The most oversaturated of his works linguistically and in terms of cultural history is Mock Faustus, still the prime example of Latvian postmodern prose (Berelis 1999: 231) - a work hardly comparable to any other piece of Soviet Latvian literature; Berelis also classifies it as a metaliterary novel (Berelis 1989: 16). Mock Faustus is a standalone and a standout novel in Latvian literature - from the perspective of language use it can be deemed a close relative to the hardly legible Finnegans Wake, by James Joyce. Wayne Booth's comment on Joyce's Ulysses and Finnegans Wake, that these texts "cannot be read; they can only be studied" (Booth 1961:325) also applies to Mock Faustus by Zarinšs, though not a lot of research on this novel exists either.

A generic term that only partially does justice to the novel by Zarinšs, drawing on the terms gastronovel and recipistolary prose, would be recipistonovel - a novel in which recipes of food play a major role in the narrative. As poiettikē in Ancient Greek denotes 'making' or 'preparing', in the context of Mock Faustus, the Ancient Greek word opso-poiètike (it means literally 'cooking, preparation of food') also comes into play, denoting cooking and an interplay of the literary and the gastronomical, rendering the novel an example of the gastroliterary. An example to illustrate this is the following: "Grāmata būs filozofiski gastronomisks traktāts, gandrīz kulinārijas un diētiskās medicīnas kandidāta disertācija, pasniegta laikmeta morāles un tikumu mērcē ar emociju salātiem" ("The book will be a philosophical-gastronomical tractatus, almost a dissertation of a candidate in culinary and dietary medicine, presented in the sauce of the morals and virtues of the times along with emotion salad'; Zariñš 1973: 9). The attention of the reader of Mock Faustus is drawn not only to the gastronomical, but also to the words used to denote the gastronomical, thus making the reader constantly shift between the poiètikē and opso-poiêtikē levels.

2 Throughout this article, for the sake of brevity, the shortened title Mock Faustus will be used; in some quotations, the abbreviation P.P.P. will be used in place of Pärlabota un papildināta pavārgrāmata. The P.P.P. is an imaginary cookbook in Mock Faustus that was published in 1880 by Jānis Vridrikisis Trampedahs, one of the main characters of the novel. 
The protean multilingual poetics of Mock Faustus uses phrases from foreign languages, dialects, different historical phases of the Latvian language, neologisms and non-literary expressions to name just a few linguistic aspects of the novel. Although most of the words present in the novel are attested in (older) dictionaries and cookbooks, when indiscriminately put together, they give the impression of Jabberwocky. The multilingualism of Mock Faustus can be described as two separate multilingualisms that are mixed throughout the novel. The first is the internal multilingualism of the Latvian language itself the different layers and epochs made into a hybrid Latvian. The second is the presence of expressions and dialogues in foreign languages.

If we take into account the ways in which multilingualism is used intratextually in novels according to Georg Kremnitz (Kremnitz 2004), then Zariņš mixes all three of the provided types: it portrays a certain realism (for example the presence of Latvian, German and Russian in everyday life, as well as Latin, Italian and French when there is reference to certain cuisines or arts); it achieves a strong Verfremdung (estrangement) effect; and the author exhibits his linguistic and cultural erudition. Multilingualism in narrative literary texts can be made visible if there is a Grundsprache (main language) present in the text (Kremnitz 2004: 14). Similarly to Finnegans Wake, where English is at least nominally the main language, in Mock Faustus, the Latvian language is only the foundation nominally. One could also agree that the use of multilingualism in novels is a strategy that shows the fragmentation of identities, both on the individual and societal levels (Kremnitz 2004: 16). Regarding the Verfremdung aspect, another parallel with Finnegans Wake should be mentioned; as Daniel Ferrer speaks about the 'English' language in Finnegans Wake, "Joyce va puissamment la transformer, y injecter de l'étrangeté, la rendre, en quelque sort, étrangère à elle-même" ('Joyce strongly changes it [i.e. the English language] by introducing strangeness to it, and in a way making it strange to itself'; Ferrer 2012: 110). This is exactly what Zariņš has done to the Latvian used in his novel. Thus, by estranging and defamiliarising the language, the individual torn by multiple regimes is also shown as being in a state of confusion.

The hybrid linguistic and gastronomical jungle can be held together only by the plot. The novel depicts events in Latvia from 1933 to 1945, during which time the governing regime changed five times. The novel consists of three parts, which can be summarised thus: 1) the early 1930s independent Republic of Latvia; 2) the First Soviet occupation (1940-1941) and German occupation of Latvia (1941-1945) with a lot of analepses to the second half of the 1930s, when Latvia was still independent but was under the authoritarian regime of Kārlis Ulmanis; 3) the end of German occupation of Latvia and the beginning of the Second Soviet occupation of Latvia, which lasted for 45 years (from 1945 to 1991). 
From one perspective, the most prominent references in the novel are those connected with many reworkings of the Faustiad. Mock Faustus, being a satirical novel of phantasmagorical expression, is regarded as a local version of The Master and Margarita (1966) by Mikhail Bulgakov (Silova 2003: 49; Gaižūns 1985). Also undeniable is the reference to Thomas Mann's Doktor Faustus (1947), as the young composer in Zariņ̧̌̌ novel, Kristofers Mārlovs, is not understood, just as Adrian Leverkühn is misunderstood in Mann's novel. Mārlovs, who is complementing and correcting the P.P.P. in order to produce his Mock Faustus, is not understood as a writer, as cookbooks, even those containing entertaining plots, are not considered real art in the world that the novel portrays. Goethe's Faust is also an apparent reference. This is true of both parts of Faust $(1808,1832)$, of which the second could be interpreted as a complement to the first part; for Zariňs it is a replay of this situation, as his Mock Faustus is, in a way, Der Tragödie zweiter Teil, as the P.P.P. is being rewritten into the Mock Faustus in the narrative of the novel.

The word 'mock' in the title points to several aspects of the novel. First is that the archetypal roles of Faustus and Mephistopheles are reversed during the events. Moreover, from the culinary perspective, cookbooks are a genre that undergoes the most changes over time, and they also signal a change of times, as the Latvian cookbook historian Astra Spalvēna argues (Spalvēna 2016). Kristofers Mārlovs is the narrator and protagonist of Mock Faustus, with both the biographical events of the sixteenth century and the fictional ones of the twentieth century mixed together. Third, in the manner of Marcel Proust's À la recherche $d u$ temps perdu, Zariņš talks about a different book, one that is in fact the book one is already reading/writing. In this way, the reader is mocked as to what he is actually reading.

Beyond these, there are uncountable other references and influences in this thoroughly intertextual work, including Shakespeare, E. T. A. Hoffmann, Rabelais and Dante and Reinis and Matīss Kaudzite, the writers of the first Latvian novel Merrnieku laiki (The Times of the Land Surveyors, 1879). The importance of food in Latvian identity was already obvious in this first Latvian novel. One of its main plot lines and themes is the wait for an honorary feast. Of special importance is the scene where the peasant imagination is brought to the extreme when the possible menu of the honorary feast is announced - a grotesque ridicule of mid-nineteenth-century Latvian peasant knowledge of

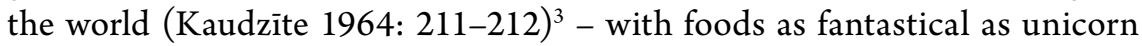
brain producing a literary menu with Rabelaisian qualities. Mock Faustus can be understood as an expansion of this passage, showing that the Latvian

For more on the utopian gastronomical grotesque, see Laizāns 2020a. 
worldview is strongly shaped by the palate and the stomach, and thereby the work comments on the Latvian way of life. Moreover, the changes to the menu under the different regimes are one of the most prominent indicators of different circumstances that come with them.

Zarinš has frequently admitted that among his inspirations for his literary gastrosymphony, both linguistically and in the use of gastronomy as a narrative vehicle, were old dictionaries - Latviešu valodas vārdnīca by Kārlis Mīlenbahs (which, ironically enough, was complemented later by Jānis Endzelīns and Edìte Hauzenberga-Šturma), Jacob Lange's Vollständiges Deutsch-Lettisches und Lettisch-Deutsches Lexikon (1777) and Georg Mancelius' Lettus, das ist Wortbuch sampt angehengtem täglichem Gebrauch der Lettischen Sprache (1638) - and sources of Livonian and Prussian languages (Silova 2004: 31), along with ancient cookbooks in the context of Latvian written language, such as Christoph Harder's Ta pirma Pawaru Grahmata no Wahzes Grahmatahm pahrtulkota ('The first [Latvian] cookbook, translated from German books'; 1795). To this Zariňš owes the gastrolinguistical style of Mock Faustus. In many parts of the book, he recreates how a Baltic German from the seventeenth or eighteenth century would have written in Latvian to the best of his knowledge - Zariņš himself being a Latvian, he adopts the same style in which Baltic Germans wrote in Latvian not as a comicality or derision, which would usually be the case, but as a means of defamiliarising the Latvian language.

The multilingualism of the novel is also a reflection on the different societies it portrays - the historical presence of peoples of both Baltic German and Russian origin has influenced everyday Latvian speech. Using a variation of expressions from several languages, Zariňš illustrates the changes of the regimes, with the social and political changes most vividly expressed by the gastronomical imagery.

An example of both the hybridity of language and the intertextual references made throughout the novel is the following. A popular food in Latvia, viltotais zakis (meatloaf, Hackbraten, falscher Hase), is among the references in the title. Zariňš explains the title in one passage of the book to be understood in gastronomical terms. A food called Mock Faustus had been supposedly invented by Erasmus of Rotterdam - a Brabantian duck grilled in tar (Zariňš 1973: 317). In a way, Zariņš tries to assert that the food is both imaginary and a literary reference, thus trying in a grotesque manner to make one think that nothing should be taken seriously. At the same time, as with all satire and grotesque, if one reads behind the imagery, one can see the political commentary and identity questions that Zarinš explores in his novel. 
The references to other cultures and languages are also produced via gastronomical imagery. An important note on how the novel should be perceived can be inferred from both the mention of the erasmian Mock Faustus and Pseudo-Virgil's work Moretum, and Zarinš interpretation of the moretum as a kind of vinaigrette. That is an example of localisation, as in Latvia vinaigrette (Lat. vinegrets) is a food that consists of beetroots, carrots and pickled cucumbers. Zariņš refers to this work by Pseudo-Virgil as Ars optima ad faciendo [sic] vinegretum divinum (The best way to prepare a divine vinaigrette) (Zariņš 1973: 316). Erasmus, in his Encomium Moriae, refers to Pseudo-Virgil's Moretum when talking about composing literary works as an entertaining rather than serious endeavour (Erasmus 1648: 11). Therefore, Zariņš makes it obscure whether his novel should be taken seriously or not by referencing a satirical text of gastronomical content and does so by recalling how Erasmus treats it as a leisurely activity. Thus, this passage by Zariņš opposes the socialist realist assumptions that literature cannot be just a game (as Zariņš treats it) but must serve a serious ideological goal.

In the context of the gastronomical aspect, which plays a major role in the commentary on various facets of social and political life in the novel, the Faustian motif must be mentioned. In this novel, it has been reduced to a sort of comicality - the highest knowledge for Mārlovs is gastronomy and cookery. In addition, the invented gastronomical romanticism (Zarinš 1973: 123) - the genre of the novel - shows the attitude towards the Latvian language. This attitude mainly consists of considering Latvian as only the ķę,ka valoda (the language of the kitchen), i.e. not a serious one from the perspective of all foreign occupant regimes. Although Zariņs shows the richness of the Latvian language in his novel, the extremes he linguistically conflates leave the readers perplexed.

Jānis Vridrikis Trampedahs is the counterpart to Mārlovs and the author of the P.P.P. Mārlovs wants to acquire the rights to this book from Trampedahs to update it once more into Mock Faustus. But it turns out that Trampedahs had only stolen from former cookbooks and had not complemented them with anything, only rearranged them - an exposure of the Baltic German hypocrisy from the perspective of Soviet ideology. Trampedahs is also a caricature of a Baltic German aristocrat (his real German name in the novel is given as Johann Friedrich Trampedach) who lives abundantly; all the pleasures of life are available to him, in contrast to the common people of Latvia, although this also points to the lavish lives of the bourgeoisie of the independent Latvia, which also brings excess. In contrast, for Mārlovs, cooking is a form of artful expression, a spiritual endeavour that can be transferred into his life's work, namely the gastronovel the P.P.P. This contrast becomes apparent in the second and third parts of the novel, in which Trampedahs corrupts Margarēta Šella (the 
Gretchen of Mock Faustus) with the new Saldā dzivve (La dolce vita). The first meal with her has to be something exceptional and extraordinary: "Maltitei jākḷūst par epigrāfu, par vadmotīvu visām turpmākajām maltītēm” ("The first meal must be an epigraph, a Leitmotiv for all the future meals'; Zarinšs 1973: 190). In time, Mārlovs wins Šella's heart, and thus Zariņš shows that true love does not need a full belly, as her life with Mārlovs is the exact opposite of the abundance that Trampedahs offers her.

The second part of the novel can, from a gastronomical perspective, be divided into two. Both the Soviet and German regimes bring with them shortages in food supply and changes to the menu. As the development and abundance of independent Latvia have ceased to exist, the narrator's attention to food diminishes, and he fails to update the P.P.P. for several years. Now everything is being prepared in the simplest way possible from the most basic ingredients available. Only in the flashbacks do recipes and extensive details of food and its consumption in the 'good old days' appear. These memories, which are mostly tied to food, function as a solace of a paradise lost. However, at the very end of this part, for the first time in the novel, something appears that is not delicious and enjoyable: "No apakšstāva rien lētas eḷlas un kāpostu dvaka" ('From the floor below comes a smell of cheap oil and cabbages'; Zariñš 1973: 310). This is also a signal of the changing times and is in contrast to the abundance during independence.

The third part is even less preoccupied with food than the second. The gastronomical, or rather the lack of it, shows disturbance and deficit, and the linguistic and narrative style differs considerably from the first part. The only good alimentary items the people have must be handed over to the Nazi Germans (Zariņš 1973: 330), and in return, the people get Bezugscheine-called

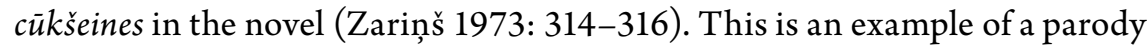
in tragedy. Cūka means 'pig' in Latvian, and in this context, it is used to denote both the attitude towards the Nazis (as pigs) and the attitude towards oneself, as if one is being treated as a pig, getting only what is suitable for pigs and, in more gastronomical terms, only getting rationed food. Mārlovs even hallucinates about food in good times and comes to the conclusion that "Pārlasot P.P.P. lappuses, viss, kas tur rakstīts, sāk likties fantastisks un nereāls" ("upon rereading the pages of P.P.P. now, everything written there seems fantastical and unreal'; Zariňš 1973: 315).

It is also important to note the attitude to the P.P.P. that different characters have throughout the novel. In the first part, it is praised as a precious artefact by both Trampedahs and Mārlovs. In the second part, Šella, echoing her leftist and socialist past, criticises the book for being idiotic - "Bet tas taču idiotiski! Non,emties ar pavārgrāmatu” ('But that is idiocy! To occupy oneself with a 
cookbook'; Zariňš 1973: 184) - as these books bring no real change for society. In the third part, the book is criticised by a 'war prisoner' who turns out to be a Soviet spy, with the criticism given in the classic hyper-didactic manner of socialist realism:

Gribēdams izbēgt no atbildības par to, kas pasaulē notiek, jūs sacerat pavārgrāmatu. Nospriedāt laikam tā: valdības nāk un iet, bet pavārgrāmatas paliek. Tā dara strauss tuksnesī, iebāž galvu smiltīs. Vai tiešām jums nekad nav bijuši draugi un lieli mērḳi?

'Wanting to escape responsibility for the events in the world you compose a cookbook. You must have thought thus: governments come and go, but cookbooks remain. An ostrich in a desert does so by putting his head in the sand. Haven't you ever had friends and great goals?' (Zarinš 1973: 330).

Thus, a cookbook, however entertaining, is not considered something one should occupy oneself much with. Again, with these assessments, Zariņš shows irony about his own work and anticipates the possible criticism towards his Mock Faustus.

The grand finale of the novel in both political and gastronomical terms is the Second Soviet occupation. The Nazi Germans have just been driven out, and a bowl of kharcho soup is offered to Mārlovs, who has been starved for ten days by Trampedahs. 'Kharcho' is the last word of the novel (Zariñš 1973: 355). It signals a new era in Latvian history as well as a new cuisine. Although known before the Soviet period, kharcho became a well-known dish in Latvia only during the Soviet era, along with other foods from the Caucasus region, such as shashlik, which is now an undisputable part of Latvian cuisine. The offering of kharcho in the novel is a sign of the beginning of a beautiful friendship that is to be developed between the nations under the hammer and sickle. It also recalls the Aristotelian golden mean: through food, the Republic of Latvia was portrayed as excessive and luxurious, and the First Soviet occupation and the German regime were portrayed as extremes of deficiency, but the Second Soviet occupation with the kharcho, whose ingredients are not too simple and not too exotic, should finally bring balance to the land and to the stomach, as well as intercultural and supranational mutual understanding.

The Latvian linguist Alberts Sarkanis adds that "Leksiskā materiāla raibums kā groteskas elements $M$. Zarin,am ir nepieciešams laikmeta, vides un varonu raksturojumam" ('The lexical palette as a grotesque technique for M. Zarinš is necessary to characterise the epoch, environment and heroes'; Sarkanis 1986). The Latvian literary critic Jānis Čākurs refers to a mystical jester who has said that "atzinis Viltoto Faustu par izdevušos dail̦arbu, tikai to vajagot pārtulkot latviešu valodā" ('the Mock Faustus is a great novel, but it 
should be translated into Latvian'; Čākurs 1973) - a remark that found (and still finds) a lot of support among readers and critics.

Marǵers Zariņš himself, after the first reactions to the publication of a fragment of the novel, said that "Uzskaititie vārdi nav paši par sevi miruši, bet gan tikai pārvietojušies. Vecākajai paaudzei - atmiṇā, jaunākajai paaudzei vārdnīcās" ('The provided words are not dead per se, but just have moved elsewhere. For the older generation - into memories, for the younger one - into dictionaries'; Zariņš 1972).

Zarinš forecasts the possible criticism in the text of the novel, and in this way, he also intertwines the first full Latvian translation of Goethe's Faust (1898), by the Latvian poet Rainis, into the text by forecasting the same reproaches that the Latvian linguist Kārlis Mīlenbahs made to Rainis - for example, the use of incomprehensible words and dialects (Gaižūns 1985), which is one of the trademarks of Mock Faustus. The translation of Goethe's Faust into Latvian by Rainis was a seminal event in the history of the Latvian language that is considered the foundation of the contemporary Latvian literary language (see Grīnuma 1999). Along with other influences, this translation was an important source of inspiration for Zariňš in how he constructed the language of his novel, although it would be hard to argue that it marked a turning point in Latvian literature. ${ }^{4}$

As a follow-up to the previous passage, the Swedish-Latvian poet Juris Kronbergs says that Mock Faustus was "pirmais spilgtākais literārās valodas identitātes problēmas pieteikums latviešu pēckara literatūrā" ('the first vivid example of the problem of identity of literary language in post-war Latvian literature'; Kronbergs 1994). The exiled Latvian literary critic Eduards Silkalns sees that the linguistic mannerisms of the novel not only express the possibilities of the Latvian language but also ridicule them:

Zariṇa aizrautība ar senvārdiem un lokālismiem [..] uzskatāms par milzīgu, gardu smieklu par 1930.-iem gadiem raksturīgo latviešu valodas latviskošanu. 'The obsession of Zariņš with archaisms and localisms [...] is to be regarded as one big, delicious laugh about the 1930s when it was characteristic to Latvianise the Latvian language.' (Silkalns 2003)

Regarding the 'Latvianisation of the Latvian language', the fact that the gastronomical language and imagery is more ample and colourful in the parts of the novel that describe the events before World War II is also an indirect evaluation

4 For example, the 2016 conceptual poetry collection Mìlākais tētis pasaulè (The Loveliest Dad in the World) by Einārs Pelšs was a threshold event in Latvian poetry; see Laizāns 2019 for a more elaborate discussion on this. 
of the times. The first part of the novel, which takes place in independent Latvia, a time when, according to myth, everything was idyllic, presents an abundance of talk about food, recipes, meals and both local and global cuisine. Though at times hyperbolic, this is in stark contrast to the chaos that follows in the subsequent two parts, in which the gastronomical reality is portrayed in bleak tones and is expressed less vividly. When Mārlovs rereads his version of the P.P.P., everything in it seems to be fantastical and unreal to him. Thus, the image of a great past has been shattered, and the future does not seem bright. Although the politics, regimes and sudden changes in relationships are addressed directly, the gastronomical side of the novel tells another story. At times, this story is quite different from the one that is directly addressed, which can even oppose the Soviet regime under which it was written, censored and published.

The aforementioned internal multilingualism, the hyperbolised mix of many varieties of Latvian and the omnipresent use of expressions from other languages reflect the constant changes to the political regimes and point to confusion in identity. However, the fact that both Mārlovs and Trampedahs are portrayed as 'eternal' figures (both are involved in sixteenth- and early seventeenth-century events as Christopher Marlowe and Ben Johnson, respectively) shows that living for several centuries brings with it an abundant thesaurus of linguistic and cultural references, which in turn confuse the reader, who has not spent so much time on this earth. The approach to poetics adapted by Zariňš also portrays how a homogeneous national Latvian language is a fiction, as is also proven by the aforementioned reactions of readers and critics: if you make something too Latvian, it does not make sense to any Latvian.

In conclusion, although the novel is a mix of gastropian and linguopian qualities and is fairly incomprehensible to a native Latvian speaker, it was translated partially or fully into eight languages between 1979 and 1988 (for example a translation into English from the Russian version by Raissa Bobrova in 1987). Just as in reality, the changes to political regimes in fictional narratives bring about the presence or absence of certain foods, and, with it, different influences on cuisine. These changes, in turn, influence language, particularly the aspects relating to gastronomy. As different regimes are inevitably tied to different nations, ethnicities and their respective languages, the portrayal of changes to political regimes through the gastronomical, however phantasmagorical, point to a reality beyond just the food on the table. All the portrayed regimes change the multilingual setup of Latvia, and as a fictional cookbook, these changes are shown most vividly by gastronomical imagery. Therefore, the only real and significant conclusion one can ever make when researching food in literature and culture is Labu apetitit! 
LAIZĀNS

\author{
Mārtiņš Laizāns \\ martins.laizans@lu.lv \\ University of Latvia \\ LATVIA
}

\title{
References
}

Barthes, R. 1961. Pour une psycho-sociologie de l'alimentation contemporaine. Annales. Economies, sociétés, civilisations, 16 (5), 977-986. https://doi.org/10.3406/ ahess.1961.420772

Berelis, G. 1989. Metaliteratūra. - Avots, 6, 15-19.

Berelis, G. 1999. Latviešu literatūras vēsture. Rīga: Zvaigzne.

Booth, W. 1961. The Rhetoric of Fiction. Chicago/London: The University of Chicago Press.

Bower, A. L. 2004. Watching Food: The Production of Food, Film, and Values. - A. L. Bower, ed., Reel Food. Essays on Film and Food. New York/London: Routledge, $1-13$.

Cozzi, A. 2010. Introduction: The Belly of a Nation. - A. Cozzi, ed., The Discourses of Food in Nineteenth-century British Fiction. Nineteenth-Century Major Lives and Letters. New York: Palgrave Macmillan, 1-18. https://doi.org/10.1057/9780230117525_1

Čākurs, J. 1973. Vēsture un literatūra, kulinārija un valodniecība ... - Karogs, 11, 162166.

Douglas, M. 1972. Deciphering a Meal. - Daedalus, 101 (1), 61-81.

Eagleton, T. 1997. Edible Ecriture. - The Times Higher Education Supplement, October 24, 1997, No. 1303 - https://www.timeshighereducation.com/features/edibleecriture/104281.article (10.11.20).

Erasmus, D. R. 1648. Moriae Encomium. Leiden: J. Maire.

Ferrer, D. 2012. Finnegans Wake ou la créativité multilingue. - O. Anokhina, dir., Multilinguisme et Créativité Littéraire. Louvain-La-Neuve: Harmattan/Academia, 109-114.

Gaižūns, S. 1985. Alķīmisku avantūru romantika jeb ceḷojumi ar Faustu pa Ventas un Daugavas krastiem. - Literatūra un Māksla, 7.

Grīnuma, G. (ed.). 1999. Rainis un Gète: "Fausta" tulkojuma simtgade. Rīga: Nordik.

Joyce, J. 1975. Finnegans Wake. London: Faber and Faber.

Kaudzīte, R., Kaudzīte, M. 1964. Mērnieku laiki. Rīga: LVI.

Kremnitz, G. 2004. Mehrsprachigkeit in der Literatur. Wie Autoren ihre Sprachen wählen. Wien: Edition Praesens.

Kronbergs, J. 1994. Latviešu literatūra pēc 1945. gada: modernisms un postmodernisms. - Literatūra un Māksla, 21(2569). 
Laizāns, M. 2019. In The Eye of the Beholder - Attitudes towards Visual Poetry in Latvian Literature. - Interlitteraria, 24 (2), 423-435. https://doi.org/10.12697/ IL.2019.24.2.12

Laizāns, M. 2020a. "Mērnieku laiki” un vienradža smadzenes: gastrotulkojuma samērojums. - E. Lāms, ed., Aktuālas problēmas literatūras un kultūras pētniecībā: rakstu krājums, 25. Liepāja: LiePA, 44-55. https://doi.org/10.37384/APLKP.2020.25.044

Laizāns, M. 2020b. Dinner with Mock Faustus: Multilingual Cuisine Cooks the Identity. - M. Pajević, Hrsg., Mehrsprachigkeit und das Politische. Tübingen: Narr Francke Attempto, 145-164.

LeBlanc, R. 1988. Dinner with Chichikov: The Fictional Meal as Narrative Device in Gogol's “Dead Souls”. - Modern Language Studies, 18 (4), 68-80. https://doi. org $/ 10.2307 / 3194724$

Lévi-Strauss, C. 1990. Mythologiques. Paris: Plon.

LSM.lv kultūras redakcija. 2017. Restorānos varēs nogaršot Latvijas rakstnieku sarakstītus ēdienus. - https://www.lsm.lv/raksts/kultura/kulturtelpa/restoranos-vares-nogarsot-latvijas-rakstnieku-sarakstitus-edienus.a259144/ (12.11.20).

Neumann, G. 1993a. Tania Blixen: Babettes Gastmahl. - A. Wierlacher, G. Neumann, H. J. Teuteberg, Hrsg., Kulturthema Essen. Ansichten und Problemfelder. Berlin: Akademie Verlag, 289-318.

Neumann, G. 1993b. Jede Nahrung ist ein Symbol. Umrisse einer Kulturwissenschaft des Essens. - A. Wierlacher, G. Neumann, H. J. Teuteberg, Hrsg., Kulturthema Essen. Ansichten und Problemfelder. Berlin: Akademie Verlag, 385-444.

Parama, R. 2002. Reading Communities and Culinary Communities: The Gastropoetics of the South Asian Diaspora. - positions, 10 (2), 471-502. https://doi. org/10.1215/10679847-10-2-471

Parasecoli, F. 2011. Savoring semiotics: food in intercultural communication. - Social Semiotics, 21 (5), 645-663. https://doi.org/10.1080/10350330.2011.578803

Radu, D. E. 2011. Joanne Harris' Gastronovels or Weaving Fiction Around Food. Annals of the University of Oradea, Romanian Language \& Literature Fascicule, 18, 117-124.

Sarkanis, A. 1986. Par izlokšṇu valodu daiḷliteratūrā un I. Indrānes romānā "Zemesvēzi dzirdēt” īpaši. - Literatūra un Māksla, 33(2175).

Shahani, G. G. 2018. Introduction. Writing on Food and Literature. - G. G. Shahani, ed., Food and Literature. Cambridge: Cambridge University Press, 1-35. https:// doi.org/10.1017/9781108661492.001

Silkalns, E. 2003. Inteliǵgents nejaucēns. - Austrālijas Latvietis, 06.08.2003.

Silova, L. 2004. ...rakstnieks Marğeris Zariņš. Rīga: Zinātne.

Spalvēna, A. 2016. Pavārgrāmatas ir laikmeta maiṇu vēstneši. - https://lr1.lsm.lv/lv/ raksts/zinamais-nezinamaja/astra-spalvena-pavargramatas-ir-laikmeta-mainuvestnesi.a70547 (10.11.20).

Tompkins, K. W. 2005. Literary Approaches to Food Studies. - Food, Culture \& Society, 8 (2), 243-258. https://doi.org/10.2752/155280105778055326 
LAIZĀNS

Witt, D. 1999. Black Hunger. Food and the Politics of U.S. Identity. New York/Oxford: Oxford University Press.

Zariņš, M. 1973. Viltotais Fausts, jeb, Pārlabota un papildināta pavārgrāmata. Rīga: Liesma. 